\title{
Parathyroidectomy under Local Anesthesia: A Case Report
}

\author{
Dr. Khalaf R Allwayzy, Prof. Dr. Mahmood A Aljumaily \\ Department of Surgery, College of Medicine, University of Mosul, Mosul, Iraq. \\ Correspondence: Khalaf R Allwayzy. khalafrasheed@yahoo.com.
}

(Ann Coll Med Mosul 2019; 41 (1):91-94).

Received: $6^{\text {th }}$ Mar. 2019; Accepted: $9^{\text {th }}$ Jun. 2019.

\section{ABSTRACT}

A fifty four years old lady presented with severe generalized bone pain, having history of multiple fractures for the last two years, biochemical tests proved to be primary hyperparathyroidism and parathyroid adenoma localized with ultrasonography. Parathyroidectomy was carried out under local anesthesia, and the patient improved dramatically after surgery.

Keywords: Hyperparathyroidism, parathyroidectomy, local anesthesia.

$$
\begin{aligned}
& \text { إستئصال الغدد جار الدرقية تحت التخدير الموضعي: تقريز حالة } \\
& \text { د. خلف رشيد اللويزي، أ.د. محمود عبد الجميلي }
\end{aligned}
$$

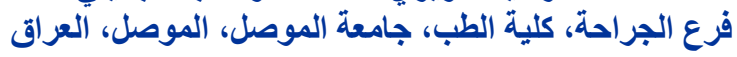

عرض لحالة مريضة في الر ابعة و الخمسين من العمر مصابة بآلام شديدة في كل العظام مع كسور متعددة حدثت بدون شدة خارجية

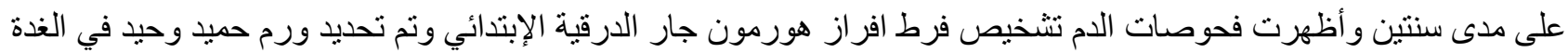

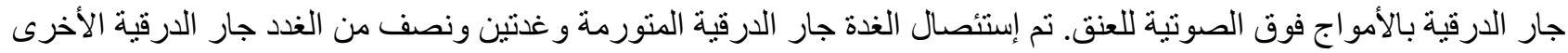

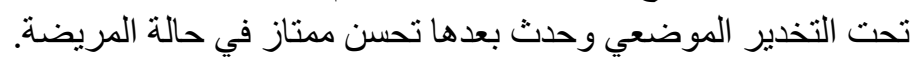

$$
\text { الكلمات المفتاحية: فرط إفراز هرمون جار الدرقية، إستئصال الغدة جار الدارية فئة الدية، التخدير الموضعي. }
$$

\section{INTRODUCTION}

$\mathrm{P}$

rimary hyperparathyroidism is a common diseases (affecting about $1 \%$ of adult population), it is either due to excessive secretion of parathyroid hormone by a single adenoma (in $85 \%$ ) or hyperplasia of parathyroid glands (in 15\%) $1,2,3$. Women are affected twice as often as in men, usually patients are middle-aged (40-65 years) $)^{1,4}$. Primary hyperparathyroidism diagnosis is based on serum calcium, phosphate and parathyroid hormone ${ }^{3}$. Parathyroidectomy is the curative treatment ${ }^{2,5,6}$. Postoperative hypocalcaemia after parathyroidectomy is expected and usually resolved after $4^{\text {th }}$ postoperative day ${ }^{6,7}$. The aim of presentation is to increase awareness of this common disease and to present the value of parathyroidectomy under local anesthesia.

\section{Case report:}

This case report was approved by the research ethics committee of college of medicine, University of Mosul. A fifty four old years women (S YS) presented at $23^{\text {th }}$ of September 2018 with severe generalized bone pain with inability to move, her complaint started two years ago as generalized bone pain with multiple fractures without trauma, fracture left shaft of femur treated surgically by plate and screws 10 months ago, lower part of right femur get fracture and treated conservatively, left forearm fractured spontaneously and treated 
conservatively ended by forearm deformity. The patient complained of anorexia, weight loss, repeated attacks of abdominal pain, polyuria, history of renal stones, repeated attacks of dysuria, sleep disturbance and depression. On examination, the patient look ill, bed ridden, cannot move here limbs with external rotation an deformity of both thighs. Left forearm was deformed, she refused any trail of passive or active movement, tenderness all over the bones, on physical examination pulse rate was 78 per minute, blood pressure was $110 / 70 \mathrm{~mm} \mathrm{mg}$, respiratory rate 18 per minute, abdomen soft and there is no palpable masses. A nodule of three $\mathrm{cm}$ diameter was found below the level of the thyroid cartilage on left side, there was no palpable lymphadenopathy in the submandibular region, no other palpable neck swelling detected.

Radiological examination of both thighs showed marked osteoporosis and multiple osteolytic lesions and cystic changes in bones. Left femur shows internal fixation by plate and screws and cystic changes in bones, right femur shows multiple cystic changes with malunited fracture in lower femur and marked osteoporosis (Fig. 1).

Pelvic x-ray shows deformity of pelvis and fracture right femoral neck with varus deformity, left femoral neck shows varus deformity of head. Left forearm show malunited fracture of distal radius and ulna with marked osteoporosis. Hand x-ray shows cortical resorption of the middle phalanges which is pathognomonic for primary hyperparathyroidism (Fig. 2).

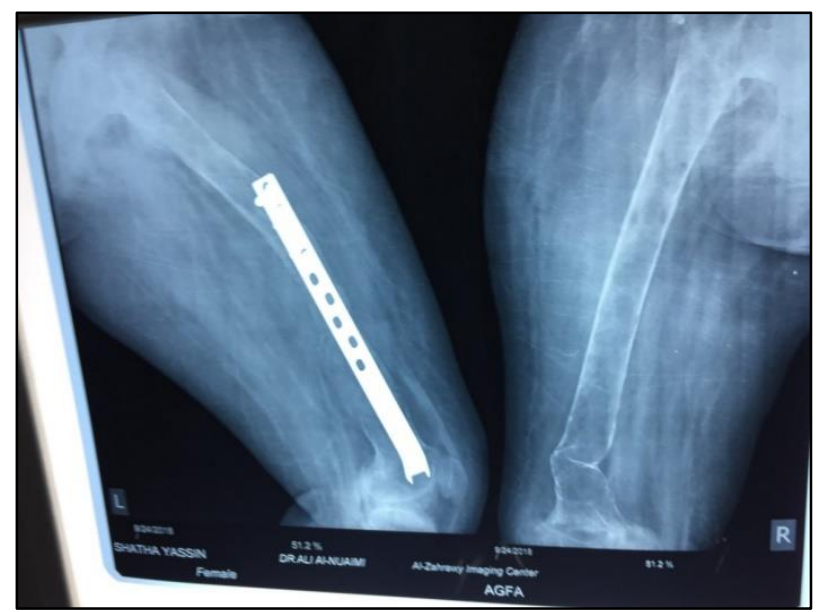

Figure 1: Radiological examination of both femora shows marked osteoporosis, multiple osteolytic lesions, cystic changes in bones, and internal fixation by plate and screws in left femur.

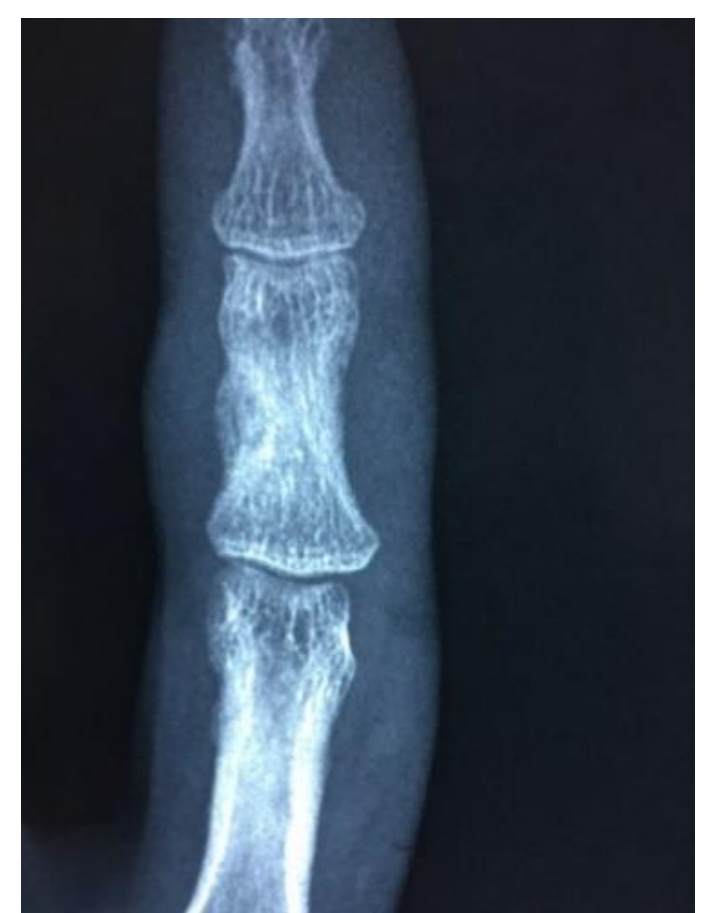

Figure 2: X- ray of right index shows cortical resorption of the middle phalanges which is pathognomonic for primary hyperparathyroidism.

Laboratory tests revealed an elevated serum calcium level of $3.1 \mathrm{mmol} / \mathrm{L}$ (normal range: $2.0-2.8$ $\mathrm{mmol} / \mathrm{L}$ ), and low serum phosphorus level of 0.72 $\mathrm{mmol} / \mathrm{L}$ (normal range: $0.81-1.65 \mathrm{mmol} / \mathrm{L}$ ). The serum alkaline phosphatase was elevated 397 IU/L (normal range: 24-82 IU/L). There was normal serum creatinine $0.9 \mathrm{mg} / \mathrm{dl}$, blood urea $18 \mathrm{mg} / \mathrm{dl}$, serum albumin $4.2 \mathrm{gm} . / \mathrm{dl}$. Serum parathyroid hormone was $1157 \mathrm{pg}$. /ml (normal range: $6.5-36.8$ ), the serum parathyroid hormone measured by chemiluminescent enzyme labeled immunometric technique (IMMULITE 1000 Siemens- Germany). Ultrasonography done to the anterior part of neck which shows well define mass at the left lower parathyroid gland, rounded, $2.5 \mathrm{~cm}$ in diameter, without cystic lesion or calcification.

The patients referred to general surgery unit on an assumptive diagnosis of primary hyperparathyroidism caused by adenoma for parathyroidectomy. The patient prepared for surgical treatment but she was unfit for general anesthesia. A decision for surgery under local anesthesia was done. At first of October 2018, the patient admitted to Alzahrawy private hospital, the patient transfer to operating room and local xylocaine infiltration $(8 \mathrm{ml}$ of $2 \%$ without 
adrenaline) was carried out with cervical plexus block, skin prepared for surgery, and through a transverse cervical collar incision, the cervical fascia is divided and muscles retracted. The thyroid gland lobes dissected and lobes retracted medially, recurrent laryngeal nerves and blood vessels identified. The adenoma of left inferior parathyroid gland identified, the other parathyroid glandes identified and look normal, the glandes excised except the deep half of right superior parathyroid gland, hemostasis carried out and wound closed in layers. Intraoperative measurement of parathyroid hormone in not applied in our patient because it is not available at time of surgery.

Intravenous fluid was given postoperatively with 10 gram calcium gluconate on fusion, daily 600000 IU of one alpha cholecalceferol intramuscularly, with repeated measurement of serum calcium in first and second postoperative days. In third postoperative day patient felt well, and she can swallow without any difficulty with normal voice, serum parathyroid hormone was $8.4 \mathrm{pg} / \mathrm{ml}$, patient discharged on 6 gram oral calcium carbonate given with $0.5 \mu \mathrm{gm}$ one alpha cholecalceferol daily, and the patient advised to drink a lot of water to maintain hydration. Histopathological examination of removed nodule confirmed the diagnosis of parathyroid adenoma. Two weeks later patient reported marked absence of bone pain, with normal serum calcium, phosphate and parathyroid hormone. The patient followed up monthly for consecutive three months, the serum calcium, phosphate and parathyroid hormone maintained normal, and the bone re-mineralized gradually.

\section{DISCUSSION}

The delay in diagnosis and treatment is expected in our local community with marked deficiency in medical care after years of destructive war in our region and wide deficiency of medical facilities. In our patient, the diagnosis of primary hyperparathyroidism was dependent on blood biochemistry, neck ultrasonography was utilized for localization of adenoma due to absences of other localization method in our medical facilities. Ultrasonography is a sensitive, specific, and costeffective imaging modality for preoperative localization, and evaluation of parathyroid adenoma size $8,9,10$. Ultrasonography had comparable accuracy to nuclear medicine -based studies (Sestambi scanning), CT scan had disadvantage of excessive irradiation, MRI is not commonly used to image the parathyroid gland ${ }^{8,9}$, ${ }^{10}$. Venous sampling and parathyroid angiography and applied for recurrence ${ }^{10}$.

Musculoskeletal system remains the most common system affected due to primary hyperparathyroidism followed by renal and gastrointestinal system ${ }^{8}$. Parathyroidectomy is successful in all patients of primary hyperparathyroidism ${ }^{10,11}$. Indication for surgical treatment of hyperparathyroidism, are marked unremitting hypercalcaemia, recurrent renal stones, nephrocalcinosis and sever bone changes 1,6,8. Excision of adenoma containing parathyroid is good option in treatment of primary hyperparathyroidism, but this diagnosis can be misleading in patients with history of chronic renal disease ${ }^{6,8}$. For this we excised two and half of other three normal looking parathyroid glands to minimize the risk of recurrence ${ }^{6,8}$. We used local anesthesia in our patient because she was unfit to general anesthesia, the local anesthesia is safe, easy to used, and reduce the complications and cost of surgery ${ }^{10}$.

Postoperative calcium supplementation is essential to prevent development of hypocalcemia. Active derivative of vitamin $D$ should be given preoperatively and postoperatively to maintain normal level of calcium ${ }^{12,13}$. Normal level of serum calcium, phosphate, parathyroid hormone in postoperative follow-up considered as full success of surgical treatment ${ }^{7,13,14}$. Lastly we should be aware about possibility of hyperparathyroidism if there is pathological fractures or generalized bone pain.

\section{REFERENCES}

1. Clark E, Tobias J. Metabolic and endocrine bone disorders. In: Blom A, Warwick D, Whitehouse MR. Apley\& Solomon's System of Orthopaedics and Trauma. 2018. $10^{\text {th }}$ ed. CRC press New York :148-149.

2. Asseeva P, Paladino NC, Guerin C. Value of ${ }^{123} \mathrm{I} /{ }^{99 \mathrm{~m}}$ Tc-sestamibi parathyroid scintigraphy with subtraction SPECT/CT in primary hyperparathyroidism for directing minimally invasive parathyroidectomy. Am J Surg 2018; 30:108-113.

3. Cetani F, Pardi E, Marcocci C. Update of parathyroid cancer. J Endocrinol Invest 2016;39: 595-596.

4. Madeo B, Kara E, Cioni K, Vezzani S, Trenti T, Santi

D. Serum calcium to phosphorous $(\mathrm{Ca} / \mathrm{P})$ Ratio is simple 
inexpensive, and accurate tool in diagnosis of primary hyperparathyroidism .JBMR Plus.2017;2(2):109-117.

5. Zou H, Song L, Jia M, Wang L, Sun Y. Brown tumor of multiple facial bones associated with primary hyperparathyroidism. Medicine (Baltimore) 2018; 97(33) : e 11877. [PubMed].

6. Al-Thani H, El-Matbouly, Al-Sulaiti M, Asim M, Majzoub A, Tabeb A, et al. Management and outcomes of hyperparathyroidism: a case series from a single institution over two decades. Ther Clin Risk Manag. 2018;14:1337-1345.

7. Anwar F, Abraham J, Nakshabandi A, Lee E. Treatment of hypocalcaemia in hungry bone syndrome: a case report. Int J Surg Case Report 2018; 51: 335339.

8. Parmar G, Chadha M. The changing face of primary hyperparathyroidism. Indian J Endocrinol Metab. 2018; $22: 299-300$.

9. Stern S, Tzelnick S, Mizrachi A, Cohen M, Shpitzer T, Bachar G. Accuracy of neck ultrasonography in predicting the size and location of parathyroid adenoma. Otolaryngol Head Neck Surg 2018; 14: 47- 65.
10. Prichard R S. The parathyroid gland. In: Williams NS, O'Connell PR, McCaskie AW. Bailey's and Love's short practice of surgery. 2018. 27 ed. Taylor \& Francis Group, LLC .p. 823- 837.

11. Saponaro F, Cetani F, Repaci U, Pagotto U, Cipriani $\mathrm{C}$, Pepe J, et al. Clinical presentation and management of patients with primary hyperparathyroidism in Italy. $\mathrm{J}$ Endocrinol Invest 2005; 28: 122-8.

12. El-Hady HA, Radwan H S. Focused parathyroidectomy for single parathyroid adenoma: a clinical account of 20 patients. Electron Physician 2018; 10(6): 6974-6980.

13. Jakubauskas $M$, Beisa V, and Strupas K. Risk factors of developing the hungry bone syndrome after parathyroidectomy for primary hyperparathyroidism. Acta Med Litu. 2018; 25(1): 45-51.

14. Pang C, Fan $Y$, Zhang $H$, Haoyong $Y$, Bomin $G$, Jie $\mathrm{K}$, et al. Case report: incidental parathyroid adenoma in a Chinese diabetic patient with hypercalcaemia and normal parathyroid hormone levels. Medicine (Baltimore) 2018;97(28):e1133. [PubMed]. 